\title{
Pemanfaatan Media untuk Meningkatkan Kesadaran Perempuan terhadap Kesehatan Reproduksi
}

\author{
Dhyah Ayu Retno Widyastuti ${ }^{*}$, Irene Santika Vidiadari ${ }^{2}$ \\ Universitas Atma Jaya Yogyakarta, Jl. Babarsari, Yogyakarta, Indonesia \\ "Corresponding Author Email: dhyah.ayu@uajy.ac.id, Telp: +6281548551056
}

\section{Received: 23 September 2019; Revised: o8 January 2021; Accepted: 11 January 2021}

\begin{abstract}
Abstrak: Media merupakan salah satu komponen komunikasi yang mempengaruhi kehidupan manusia sehari-hari. Pada masyarakat yang cenderung aktif, mereka bisa menyeleksi informasi yang ingin dikonsumsi. Namun realitanya, terdapat kondisi perempuan yang harus bekerja di wilayah domestik dengan keterbatasan kemampuan dalam mengakses informasi. Berdasar realita ini, dibutuhkan sebuah program pendampingan literasi media untuk perempuan. Program pendampingan yang dirancang mengombinasikan isu kesehatan reproduksi dan isu pemanfaatan media. Program kegiatan yang dilaksanakan oleh tim meliputi (1) Pengenalan media komunikasi; (2) Pemanfaatan media sebagai sumber informasi dan literasi media; (3) Keterkaitan media dengan kesehatan reproduksi dan pendampingan kesehatan reproduksi remaja. Simpulan dari kegiatan pendampingan ini adalah (a) Melalui kegiatan pengabdian ini, tim melihat bahwa terdapat peningkatan pemahaman dan pengetahuan keberadaan jenisjenis media sosial dan fungsinya; (b) Kelompok sasaran mengakses informasi media sosial yang relevan dengan kebutuhan mereka sehari-hari dalam rangka mendampingi anak; (c) Kelompok sasaran dapat memanfaatkan akses informasi mengenai kesehatan reproduksi; (d) Kemampuan menyaring berita yang tidak benar (hoaks) yang tersebar melalui media sosial yang mereka miliki.
\end{abstract}

Kata Kunci: Literasi Media, Kesehatan Reproduksi, Pemanfaatan Media, Perempuan

\section{Using Media to Increase Awareness of Women's Reproductive Health}

\begin{abstract}
Communication media is one component of communication that affects human life. For active communities, they can select the information they want to consume. However, there are conditions for women who have to work in domestic areas with limited ability to access information. From this reality, it takes a media literacy program for women. The mentoring program designed combines reproductive health issues and issues of media use. The program activities carried out by the team include (1) Introduction of communication media; (2) Use of the media as a source of information and media literacy; (3) The concept of reproductive health and assisting reproductive health for teenagers. The conclusions from this mentoring activities are (a) Through this service activities, the team see there is an increase in understanding of social media's variations and their functions;(b) Target groups access social media that is relevant to their daily needs in order to assist their children; (c) Target groups can use access to information on reproductive health; (d) The ability to filter hoax news spread through social media they have.
\end{abstract}

Keywords: Media literacy, Reproduction health, Utilization of communication media, Women

How to Cite: Widyastuti, Dhyah Ayu Retno Widyastuti, Vidadari, Irene Santika Vidiadari (2021). Pemanfaatan Media untuk Meningkatkan Kesadaran Perempuan terhadap Kesehatan Reproduksi. JPPM (Jurnal Pendidikan dan Pemberdayaan Masyarakat), 8(1), 18-29. Doi: https://doi.org/10.21831/jppm.v8i1.27263 


\section{PENDAHULUAN}

Perempuan di Indonesia menghadapi setidaknya enam masalah besar. Institut Kapal Perempuan mengemukakan enam masalah tersebut antara lain: diskriminasi, kekerasan, praktik berbahaya terhadap perempuan (misalnya pernikahan paksa, pernikahan dini, dan sunat perempuan), kurangnya penghargaan terhadap pekerjaan rumah tangga yang dilakukan perempuan, kurangnya partisipasi aktif perempuan dalam berbagai bidang, serta kurangnya akses perempuan terhadap kesehatan seksual dan reproduksi (Kapal perempuan, 2018).

Enam masalah yang dihadapi perempuan jelas memiliki dampak yang signifikan, salah satunya pada persoalan perdagangan orang.Pada kasus-kasus perdagangan perempuan, tidak hanya perempuan dewasa yang menjadi korban, tetapi juga yang di bawah umur. Hal ini yang menyebabkan pembahasan mengenai perdagangan perempuan selalu dikaitkan dengan persoalan perdagangan anak di bawah umur (Pudjiastuti, 2016). Data dari Bareskim Polri, bahwa pada tahun 2012-2015 terdapat 861 kasus perdagangan orang, 70\% korbannya adalah perempuan dan anak (Saroh, 2016). Perempuan dan anak yang menjadi korban perdagangan manusia menempatkan keduanya sebagai pihak yang paling berisiko dan rentan secara fisik dan mental (Pudjiastuti, 2016).

Salah satu akar penyebab masalah perempuan adalah kurangnya akses kesehatan reproduksi bagi perempuan menyebabkan tingginya angka pernikahan usia dini di kalangan perempuan remaja. Margaretha Sitanggang (Wardhani, 2017; Birowo, 2019) mengemukakan bahwa sekarang ini terdapat 1,7 juta perempuan muda yang berusia di bawah 24 tahun pernah melahirkan dan 500.000 di antaranya adalah remaja berusia di bawah 18 tahun. Dampak selanjutnya yang dihadapi perempuan remaja ini adalah berkurangnya kesempatan bekerja, mengembangkan usaha dan melanjutkan pendidikan. Rendahnya tingkat pendidikan perempuan berpengaruh pada pola asuh anak, dan yang pasti akan berpengaruh pada rendahnya tingkat kesejahteraan keluarga karena sempitnya kesempatan kerja.

Kesejahteraan keluarga sangat bergantung pada kemandirian keluarga itu sendiri. Undang-Undang no. 10 tahun 1992 tentang Perkembangan Kependudukan dan Pembangunan Keluarga Sejahtera menyebutkan bahwa kemandirian keluarga adalah sikap mental dalam hal berupaya meningkatkan kepedulian masyarakat dalam pembangunan, mendewasakan usia perkawinan, membina dan meningkatkan ketahanan keluarga, mengatur kelahiran dan mengembangkan kualitas dan kesejahteraan keluarga, berdasarkan kesadaran dan tanggung jawab. Berdasar definisi ini, menunjukkan bahwa kemandirian keluarga merupakan aspek penting dalam mewujudkan kesejahteraan penduduk (Undang-Undang no. 10 tahun 1992 tentang Perkembangan Kependudukan dan Pembangunan Keluarga Sejahtera., n.d.).

Di sisi lain, menurut Friedman (Friedman, 1998), keluarga sebagai unit terkecil dalam masyarakat menjalankan 5 fungsi penting, salah duanyanya adalah fungsi reproduksi dan fungsi pemeliharaan, terutama pada persoalan untuk mempertahankan kelangsungan generasi dan memelihara mempertahankan keadaan kesehatan anggota keluarga agar tetap memiliki produktivitas yang tinggi. Secara leih mendalam terkait dengan pendidikan seksual dan kesehatan reproduksi bagi anak merupakan tanggung jawab orang tua, guru, masyarakat, dan pemerintah (Astuti, Sugiyatno, Aminah, 2017).

Kegiatan pelatihan untuk meningkatkan kesejahteraan dan kemandirian keluarga yang paling strategis diberikan kepada kelompok perempuan. Ragam kegiatan untuk meningkatkan kapasitas perempuan antara lain pelatihan pengelolaan bahan pangan lokal yang dilakukan oleh Saugi dan Sumarno (2015). pada kegiatan pengabdian yang dilakukan, pengolahan bahan pangan lokal membantu masyarakat setempat untuk meningkatkan pendapatannya melalui usaha UMKM serta variasi produk dari usaha yang dijalankan. Upaya peningkatan kapasitas perempuan lainnya dilakukan oleh Saripah dan Shantini (2016) yang melakukan pelatihan kecakapan hidup perempuan di Ujungberung. Pelatihan lain yang pernah dilakukan adalah pelatihan pengolahan sampah bagi kelompok PKK yang dilakukan oleh Rivo Nugroho (2017). Pasca pelatihan pengelolaan 
sampah, Nugroho (2017) meneliti dan menemukan bahwa keberdayaan perempuan di kelompok PKK tersebut meningkat 82,5\%.

Pelatihan yang diberikan kepada kelompok perempuan lebih banyak mengacu pada pemenuhan kebutuhan ekonomi, namun masih jarang yang melihat pada pemenuhan hak perempuan untuk mendapatkan kondisi reproduksi yang sehat. Mempertimbangkan bahwa reproduksi menjadi salah satu fungsi yang perlu dijalankan dalam sebuah keluarga, maka pengetahuan tentang kesehatan reproduksi menjadi salah satu aspek penting yang perlu disampaikan khususnya kepada perempuan. Hal ini dikarenakan perempuan memegang peranan penting untuk terwujudnya kemandirian keluarga. Kondisi kurangnya pengetahuan reproduksi dalam keluarga berdampak pada aspek kehidupan seperti perilaku seks dan kehamilan remaja. Data statistik tahun 2013 menunjukkan bahwa di propinsi D.I. Yogyakarta (baik di perkotaan maupun pedesaan) terdapat 25,57\% pernikahan remaja di bawah usia 18 tahun. Temuan mengenai angka pernikahan remaja ini juga didukung oleh penelitian yang dilakukan oleh Aprilia (Aprilia, 2016) yang menunjukkan bahwa kurangnya pemahaman remaja tentang kesehatan reproduksi selama masa puber mengakibatkan perilaku beresiko pada remaja tersebut. Berangkat dari persoalan ini, dapat dilihat bahwa kemandirian keluarga dalam pendampingan anak berpengaruh pada rendahnya tingkat kehamilan remaja.

Persoalan minimnya pengetahuan mengenai kesehatan reproduksi di atas timpang dengan arus informasi yang melimpah karena adanya media. Media merupakan salah satu komponen komunikasi yang mempengaruhi kehidupan manusia sehari-hari. Media membantu masyarakat untuk memperoleh informasi mengenai berbagai bidang baik ekonomi, sosial, politik, maupun budaya. Melalui berbagai format media mampu memberikan informasi yang bersifat menghibur, membujuk, maupun memberikan nilai tambah terhadap apa yang diinformasikan. Terlebih di pulau Jawa (Nielsen, 2014) mengemukakan bahwa 33\% masyarakat di pulau Jawa mengakses internet. Pada masyarakat yang cenderung aktif, mereka bisa menyeleksi informasi yang ingin mereka konsumsi. Idealnya, melalui internet, perempuan dapat mengakses informasi terkait kesehatan reproduksi, menambah pengetahuan untuk memberdayakan dirinya, serta memperoleh informasi mengenai perlindungan perempuan dan anak. Namun hal yang berbeda terjadi ketika berhadapan pada kondisi masyarakat yang memiliki keterbatasan kemampuan baik dari segi akses media maupun dari aspek tataran pengetahuan.

Plumbon merupakan satu dari sebelas dukuh yang ada di Kecamatan Banguntapan, Kabupaten Bantul. Komposisi jumlah penduduk di Kecamatan Kecamatan Banguntapan yaitu terdiri dari 17.147 kepala keluarga (KK). Jumlah keseluruhan penduduk Kecamatan Banguntapan adalah 76.513 orang dengan berbandingan jumlah penduduk laki-laki sebanyak 37.752 orang dan penduduk perempuan 38.761 orang. Data ini menunjukkan besarnya jumlah penduduk berjenis kelamin perempuan. Sedangkan berdasarkan jenis pekerjaan sebanyak 3.653 perempuan di kecamatan Banguntapan bekerja mengurus rumah tangga. Tingginya jumlah perempuan yang bekerja di wilayah domestik, tentu berpengaruh pada akses informasi yang mereka miliki. Pada program pendampingan ini secara spesifik dilakukan di salah satu wilayah dukuh Plumbon, yaitu Sanggrahan.

Sebagai gambaran, penduduk yang tinggal di wilayah Sanggrahan RT 11/9 terdiri dari 30 KK. Kegiatan rutin yang dilakukan oleh anggota masyarakat Sanggrahan salah satunya adalah arisan PKK. Mereka tergabung dalam satu kelompok arisan yang secara rutin dilaksanakan setiap bulan pada tanggal 17. Bila dipetakan berdasarkan jenis pekerjaan bahwa paling dominan adalah jumlah perempuan yang bekerja di wilayah domestik sebagai ibu rumah tangga yaitu sebanyak $75 \%$, dan sisanya $25 \%$ sebagai buruh baik bekerja di perusahaan konveksi, penerbitan, perawat, dinas pemerintah, dan guru.

Salah satu dinamika yang muncul pada kondisi perempuan dan anak di daerah ini salah satunya adalah perkawinan usia dini. Ini sebagai gambaran realitas bagaimana kesadaran terhadap kesehatan reproduksi belum menjadi satu hal yang penting bagi masyarakat. Padahal seharusnya kesehatan perempuan merupakan aspek paling penting disebabkan pengaruhnya 
pada kesehatan anak-anak. Oleh sebab itu, perempuan diberi kebebasan dalam menentukan hal yang paling baik demi kesejahteraan dan kemandirian keluarga. Namun realitasnya di wilayah Sanggrahan ini terdapat keterbatasan bagi perempuan dalam akses baik di bidang pendidikan maupun pekerjaan. Atas dasar uraian ini, tim membuat program pendampingan pada perempuan yang tergabung dalam kelompok arisan PKK di RT 11/o9 Sanggrahan, Dukuh Plumbon, Kecamatan Banguntapan, Kabupaten Bantul.

Perkembangan berbagai media komunikasi dan informasi tentu memudahkan masyarakat untuk mengakses segala kebutuhan mereka (Widyastuti et.al., 2016). Media menyajikan informasi dengan berbagai cara. Kondisi ini tergambarkan juga di masyarakat wilayah Sanggrahan dengan adanya dinamika penggunaan smartphone yang cukup tinggi. Oleh karena itu dalam rancangan pendampingan ini, kami menekankan pada pemanfaatan media informasi dan komunikasi yang memungkinkan kelompok sasaran menggunakannya untuk aktivitas yang lebih bermanfaat. Ini merupakan salah satu wujud pemberdayaan masyarakat. Pemberdayaan dilakukan sekaligus memberikan pembelajaran bagi masyarakat (Widodo, 2018), terutama dalam hal ini terkait dengan literasi media dan kesehatan reproduksi.

Merujuk pada deklarasi UNESCO mengenai literasi informasi bahwa kegiatan ini dilakukan untuk membangun kemampuan masyarakat dalam mengidentifikasi, menentukan, menemukan, mengevaluasi, menciptakan secara efektif dan terorganisasi, menggunakan dan mengomunikasikan informasi untuk mengatasi berbagai persoalan (Prasanti, D., 2017; Juditha, 2019). Seiring maraknya media digital maka literasi digital pun penting sebagai pondasi bagi masyarakat dalam mengonsumsi informasi (Widyastuti, D.A.R., Ranggabumi, N., Thomas, 2016). Atas dasar ini, program yang kami rancang yaitu pemanfaatan media untuk meningkatkan kesadaran perempuan terhadap kesehatan reproduksi dalam upaya mencapai kemandirian keluarga.

Harapannya, melalui pendampingan ini memberi bekal bagi perempuan untuk membangun kapasitas kemandirian yang berangkat dari kesadaran akan pentingnya kesehatan reproduksi. Selain itu mereka bisa menyadari bahwa penggunaan media dalam kehidupan sehari-hari bisa lebih optimal untuk menunjang aktivitas yang lebih produktif.

\section{METODE}

Program pengabdian kepada masyarakat dilakukan di Plumbon, Banguntapan, Bantul atas dasar kebutuhan dan persoalan yang ada di lingkungan masyarakat setempat. Durasi pelaksanaan kurang lebih selama enam bulan melalui tahapan yang dilakukan secara berkesinambungan. Dalam proses pendampingan, penulis menggali berbagai informasi yang relevan dengan tema dengan cara melakukan focus group discussion (FGD) dan observasi. Data selanjutnya dengan memilahkan terlebih dahulu informasi yang relevan kemudian merancang program yang relevan pada kelompok sasaran.

Berdasarkan uraian gambaran kondisi pada kelompok sasaran terutama perempuan di wilayah Plumbon maka metode pendampingan yang ditetapkan meliputi tahapan persiapan, tahap pelaksanaan, dan tahap pelatihan. (1) Tahap persiapan merupakan tahapan dilakukan identifikasi masalah dan persiapan materi. Tim penulis mengidentifikasi segala permasalahan mengenai segala hal yang dapat diselesaikan melalui program pengabdian masyarakat ini. Proses identifikasi masalah juga merupakan hasil diskusi yang mendalam antara tim penulis dengan ibu ketua RT di wilayah Sanggrahan, Dukuh Banguntapan. Setelah melakukan identifikasi masalah, penulis akan melakukan literature review dalam proses persiapan materi yang akan disampaikan kepada target audiens. Konteks permasalahan yang terjadi menjadi pedoman penting bagi tim penulis untuk menyusun materi serta memilih teknik penyampaian materi yang tepat bagi target audiens agar materi dapat dipahami secara efektif dan holistik. (2) Tahap pelatihan merupakan pemberian materi sesuai dengan kondisi yang ada pada kelompok sasaran diantaranya pemahaman konsep gender dan kesehatan reproduksi, pemanfaatan media 
sebagai sumber informasi bagi perempuan, dan literasi media. (3) Tahap akhir adalah laporan yakni terkait evaluasi program yang dilaksanakan pada kelompok pendampingan.

\section{HASIL DAN PEMBAHASAN}

Perkembangan teknologi komunikasi dan informasi saat ini mendukung seorang individu yang ingin secara mandiri membangun pengetahuan baru, berkomunikasi dengan orang lain, hingga menginisiasi gerakan komunal lewat pemanfaatan media digital. Pada proses pemanfaatan media digital, perlu sebuah kecakapan yang disebut literasi media. Hingga seiring perekembangannya, konsep literasi media bertransformasi seiring perkembangan teknologi informasi dan komunikasi menjadi literasi digital (Limilia dan Aristi, 2019). Literasi media, terutama pada media digital adalah sebuah sikap dan kemampuan individu mengakses teknologi dan perangkat komunikasi untuk mencari informasi, mengelola, mengintegrasikan, menganalisis dan mengevaluasi informasi (Setyaningsih, R., Abdullah, Prihantoro, E., 2019).

Joint Information System Committee (JISC, 2014) mengemukakan bahwa dalam proses membangun kecakapan literasi, setidaknya ada tujuh elemen penting yang perlu dipelajari, tiga diantaranya yang dipraktikkan dalam kegiatan pengabdian ini adalah: (1) proses literasi informasi, yakni kecakapan mencari, menemukan, menginterpretasikan, mengevaluasi, mengatur dan membagikan informasi. (2) Keterampilan menggunakan media digital untuk belajar secara efektif, dan (3) Literasi media digital, sebuah kecakapan mengadopsi dan memanfaatkan media digital. Kegiatan pengabdian kepada masyarakat dilakukan melalui beberapa tahapan di antaranya (a) Kegiatan pertama, materi ini berfokus pada pengenalan jenis media, media sosial, hingga mengenal aplikasi media sosial yang terdapat di gawai pintar (Smartphone) kepada perempuan (ibu-ibu) melalui fórum PKK. Materi diawali dengan pengenalan pemahaman media komunikasi dan menggali pengetahuan tentang media yang diakses oleh perempuan. Pemateri memberikan penjelasan mengenai jenis-jenis media komunikasi dan fungsi media komunikasi (fungsi hiburan, menyampaikan informasi, edukasi, bisnis dan politik). Penjelasan mengenai kehadiran internet dan media sosial yang sekarang banyak diakses, pemaparan jenis dan fungsi masing-masing media sosial.

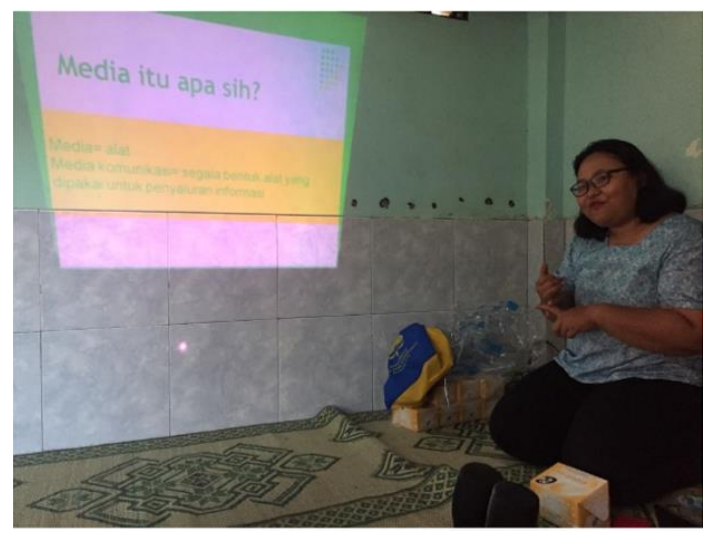

Gambar 1. Tim memberi materi Sumber: Dokumentasi Tim, 2018

Kegiatan kedua, pemberian materi diawali dengan menggali pengalaman bermedia ibuibu PKK dan mencari tahu informasi yang diakses melalui media. Pada tahap ini pemateri menggali media apa yang paling banyak diakses dan tujuan dari mengakses media tersebut. Pemateri memberikan pemahaman tentang media internet sebagai media interaktif yang memberikan banyak manfaat. Manfaat internet antara lain menjadi perpustakaan terbesar di dunia, mempertemukan jutaan orang di dunia, dan menjadi tempat untuk membuka usahasalah satunya penerbit. Pada proses pencarian, para perempuan dapat menggunakan aplikasi 
browser dan mencari dengan kata kunci tertentu. Kemudahan lain dari internet adalah konektivitas, para ibu dapat terhubung dengan anggota keluarga yang berada di tempat yang jauh. Kelemahan dari internet yang biasanya diakses melalui gawai pintar adalah pengawasan yang lemah karena sifatnya privat. Oleh karena itu, saat mengawasi anak yang sedang menggunakan gawai, para ibu diajak untuk selalu mendampingi anak pada saat mereka menggunakan gawai.

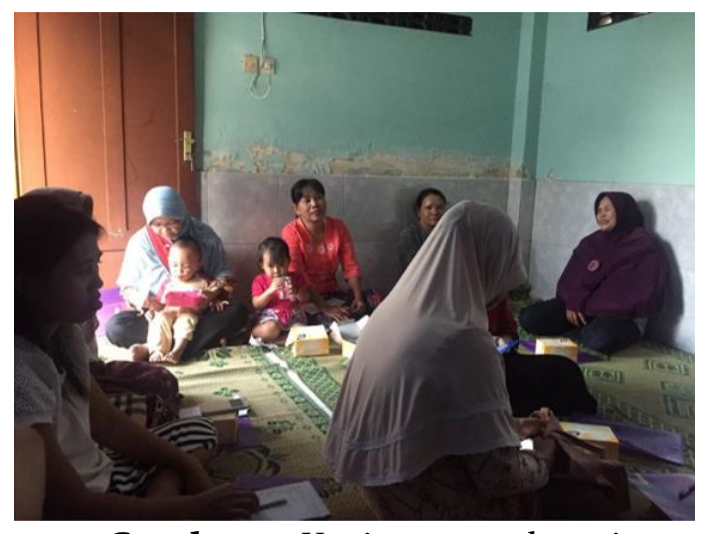

Gambar 2. Kegiatan pendampingan

Sumber: Dokumentasi Tim, 2018

Kegiatan ketiga, pelatihan ini diawali dengan pemaparan data pengguna internet di Indonesia berdasarkan kelompok usia. Melalui data ini dapat dilihat bahwa pengguna internet di usia remaja adalah salah satu kelompok usia terbesar. Materi selanjutnya adalah mengenai penggunaan gawai pintar oleh anak. Penggunaan gawai pintar oleh anak mengganggu kemampuan motorik anak seperti kemampuan mengikat sepatu, bersepeda, maupun berenang. Guna menyeimbangkan kegiatan anak, perlu kesepakatan antara orang tua anak mengenai waktu untuk menggunakan gawai, dengan pendampingan orang tua dan di tempat tertentu yang telah disepakati. Materi literasi media diberikan terutama untuk meredam penyebaran verita tidak benar (hoaks) melalui media sosial. Literasi media penting dilakukan di lingkungan masyarakat secara umum (Friesem, 2016). Pemateri memberikan ciri-ciri berita hoaks antara lain: judulnya biasanya provokatif, alamt situs tidak jelas, gambar yang tercantum tidak sesuai fakta, sehingga fakta dari berita tersebut perlu diverifikasi. Pemateri memberikan saran untuk para ibu untuk tidak terburu-buru menyebarkan berita tanpa mencari tahu apakah berita itu benar atau tidak, tidak menyebarkan foto korban kecelakaan melalui media karena hal tersebut tidak etis. Selanjutnya untuk meningkatkan kesadaran para ibu, disarankan untuk mengikuti forum-forum yang bergerak di bidang menangkal berita hoaks seperti Forum Anti Fitnah, Hasut dan Hoaks, Grup Sekoci, dan lainnya.

European Commission Directorate General Information Society and Media (2009) mengemukakan bahwa terdapat 3 level kompetensi literasi media: level dasar, level menengah, dan level lanjutan. Pada level dasar, individu mengetahui fungsi dasar media sebagai perangkat penerima dan pengirim informasi, mampu menggunakan media pada fungsi dasarnya dan secara terbatas mampu menganalisis informasi yang diterima. Pada level menengah, individu mulai fasih mengoperasikan media digital, menerima dan mengevaluasi sebuah informasi dengan lebih kompleks, memilah informasi yang dibutuhkan dan dapat meningkatkan strategi pencarian informasi. Pada level lanjutan, seorang individu dapat memanfaatkan media tidak hanya untuk mencari informasi, tetapi juga menginisiasi kegiatan komunal untuk menyelesaikan masalah tertentu (European Commission Directorate General Information Society and Media, 2009).

Pada kegiatan pengabdian kepada masyarakat ini, tujuan dari pemberian materi tentang mengenal jenis media hingga cara identifikasi hoaks ini bertujuan agar komunitas setidaknya mampu mencapai kompetensi literasi media digital di level menengah, yakni agar komunitas 
mampu dengan fasih memanfaatkan media digital untuk mencari dan memanfaatkan informasi. Manfaat lebih lanjut adalah agar para peserta pelatihan ini mampu mendampingi anak-anaknya saat memanfaatkan media digital.

Kegiatan keempat, tema yang diambil adalah "Memahami Konsep Gender dan Pembagian Peran dalam Pengasuhan Anak". Menggali pengalaman para ibu PKK tentang pembagian kerja dalam rumah tangga, antara ibu dan bapak terutama tentang pola pengasuhan anak. Mengenalkan konsep gender, peran gender dan pembagian kerja antara laki-laki dan perempuan. Mendeskripsikan tentang pembagian peran antara ibu dan bapak dalam pendampingan anak disertai contoh-contoh. Para perempuan diajak untuk mempersuasi kepada para suaminya untuk ikut serta dalam proses pengasuhan anak. Terutama bagi yang memiliki anak yang remaja atau menjelang remaja. Pembagian peran antara ibu dan bapak salah satunya adalah pada saat memperkenalkan tentang kesehatan reproduksi kepada anak dan menyediakan diri sebagai tempat bertanya anak mengenai tubuhnya dan organ reproduksinya

Kegiatan kelima, mengambil tema "Memahami Konsep Kesehatan Reproduksi". Kesehatan reproduksi merupakan aspek penting dalam upaya menjaga kesehatan namun sering kali dianggap sebagai hal yang tabu untuk diungkapkan. Mengenal kesehatan reproduksi berarti mengenal tubuh masing-masing. Para ibu diberi pemahaman tentang fungsi alat reproduksi perempuan dan laki-laki dengan menggunakan alat peraga. Pengenalan proses terjadinya mimpi basah dan menstrusasi. Orang tua memiliki tanggung jawab untuk mengenalkan tentang organ reproduksi pada anak dan memberikan bekal bagaimana menjaga kesehatan organ reproduksi tersebut. Orang tua perlu menjelaskan kepada anak bagaimana menjaga keselamatan diri sendiri, terutama ketika bertemu orang-orang asing maupun yang dikenal dan mulai memegang area-area tubuh yang tidak sepantasnya disentuh. Mengenalkan kepada orang tua area tubuh anak yang tidak boleh disentuh orang asing seperti dada dan area kelamin. Pada kegiatan ini perempuan diberi bekal tentang bagaimana memberi jawaban kepada anak yang bertanya seputar kesehatan reproduksinya.

Kegiatan keenam, yaitu mengenai Peran Orang Tua dalam Pendidikan Seks Remaja. Materi diawali dengan pemaparan mengenai masalah yang dihadapi remaja masa kini antara lain: Kehamilan Tidak Diinginkan (KTD), Aborsi, Infeksi Menular Seksual, Kekerasan dalam Pacaran, pornografi. Hasil penelitian dari pusat Studi Gender UI mengemukakan bahwa remaja biasanya mencari informasi tentang seksualitas di sekolah, orang tua, media dan teman. Namun sayangnya, dari pihak guru, ada $65,5 \%$ guru sekolah yang memiliki hambatan dalam menyampaikan pendidikan kesehatan reproduksi. Atas dasar ini, orang tua harus hadir untuk melengkapi penyampaian guru tentang kesehatan reproduksi dengan nilai-nilai keluarga. Pendidikan seks diperlukan agar mencapai tujuan berikut: anak mampu melindungi diri dari resiko ancaman kesehatan reproduksi, anak mampu menolak perilaku seksual dan mampu mengelola dorongan seksual. Pendidikan seksual dilakukan secara bertahap, dan ketika anak sudah siap. Orang tua perlu membiasakan untuk memasukkan isu kesehatan reproduksi dalam obrolan sehari-hari dan diawali dengan mengidentifikasi perbedaan jenis kelamin. Orang tua perlu memberikan pemahaman tentang masa pubertas, perubahan tubuh yang terjadi dan cara menjaga kebersihan organ kelamin. 


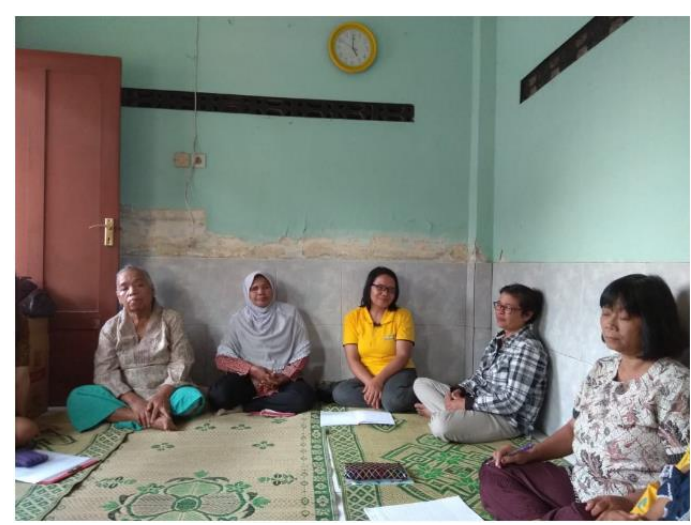

Gambar 3. Kegiatan pendampingan Sumber: Dokumentasi Tim, 2018

Program pendampingan yang dilaksanakan mempunyai luaran kegiatan sebagai solusi yang relevan bagi kelompok sasaran. Dalam hal ini bentuk program berupa model distribusi informasi (transfer knowledge) mengenai pemanfaatan media sebagai sumber informasi bagi perempuan mengenai kesehatan reproduksi. Hasil yakni berupa pemahaman kelompok sasaran secara substansi mengenai isu terkait. Adapun, luaran yang tampak bahwa kelompok sasaran mempu memanfaatkan media secara bijak terutama bahwa media bukan hanya sebagai perangkat untuk memperoleh informasi atau menyebarkan informasi namun mereka mampu menyaring informasi yang relevan dengan kebutuhan baik untuk diri pribadi, lingkungan keluarga, maupun lingkungan masyarakat.

Pada bagian evaluasi penulis berangkat dari dukungan yang diberikan kelompok sasaran selama pelatihan, pemetaan kondisi yang terjadi selama pelatihan dan selanjutnya membuat ulasan pembahasan terkait dengan dinamika yang ada.

Dukungan dari kelompok sasaran selama pelatihan di antaranya:

1. Koordinasi terkait dengan pengumpulan peserta

2. Ruang pertemuan yang lengkap dengan fasilitas yang memungkinkan untuk menggunakan media digital yang digunakan sebagai sarana pendukung

Terdapat beberapa kondisi yang menjadi temuan selama pelatihan yaitu:

1. Persoalan Teknis

a. Ketersediaan waktu dari peserta kelompok sasaran terbatas

Hal ini dialami oleh tim karena kelompok sasaran memiliki beragam aktivitas. Misalnya yang memiliki pekerjaan sebagai ibu rumah tangga secara fleksibel menyediakan waktu untuk pendampingan di siang hari. Namun sebagian perempuan yang bekerja di ranah publik hanya bisa mengikuti pada saat sore hari di mana sebagian besar dari ibu-ibu yang pekerjaan utamanya sebagai ibu rumah tangga harus memasak untuk pemenuhan kebutuhan keluarga mereka. Dalam persoalan ini akhirnya disepakati bahwa pendampingan dilakukan bersamaan dengan kegiatan arisan yang telah terjadwal setiap bulannya pada tanggal 17 .

b. Dua pintu koordinasi

Pada kelompok sasaran terdapat dua pintu koordinasi. Artinya bahwa terdapat dua orang yang dominan dan mempengaruhi pengambilan keputusan kelompok. Bukan hanya berkoordinasi dengan ketua perkumpulan namun tim perlu berkoodinasi dengan orang yang memiliki keterlibatan aktif di lingkungan kelurahan.

2. Persoalan Substansi

a. Latar belakang pekerjaan peserta kegiatan berbeda-beda

Kelompok sasaran memiliki pekerjaan yang beragam. Jumlah peserta pendampingan adalah 25 orang dengan $70 \%$ bekerja sebagai ibu rumah tangga dan sisanya ada yang bekerja sebagai perawat, buruh pabrik, percetakan, memiliki usaha 
warung makan, dan wirausaha. Beberapa ibu rumah tangga memiliki pekerjaan sampingan yakni membuka toko kelontong di rumah mereka.

Jumlah 30\% peserta yang bekerja di wilayah publik ini secara aktif menggunakan handphone dalam mengakses informasi, dan cenderung mengetahui istilah fitur-fitur dan penggunaannya. Berbeda dengan yang pekerjaan utamanya sebagai ibu rumah tangga mereka memiliki keterbatasan pendidikan sehingga dari sebagian yang mengakses media digital tidak sepenuhnya memahami fungsi fitur yang tersedia dan penggunaannya.

b. Kecenderungan peserta merupakan pemula pengguna media digital

Sebagian dari peserta pendampingan merupakan pengguna awal media digital. Hal ini muncul dari beberapa ungkapan peserta pada awal pendampingan. Sebagian merupakan pengguna transisi, artinya semula sudah menggunakan fasilitas handphone namun belum tersambung dengan internet dan berganti dengan handphone dengan sistem operasi (IOS) Android yang memungkinkan dapat mengakses internet.

c. Sebagian peserta agresif dalam menggunakan media digital

Pengguna transisi ini bisa dikatakan mereka agresif dalam menggunakan smartphone terutama media sosial yakni whatsapp (WA). WA merupakan aplikasi dominan yang digunakan oleh kelompok perempuan dalam mengakses informasi dan menyebarkan informasi. Berdasar observasi kecenderungan mereka bersifat agresif dalam menyikapi informasi yang tersebar di WA. Mereka belum selektif dalam memilih dan menyebarkan informasi yang mereka konsumsi di mesia sosial sehingga tidak terhindarkan juga penyebarluasan hoaks baik sifatnya berita atau himbauan-himbauan yang menyesatkan. Sebagai contoh:

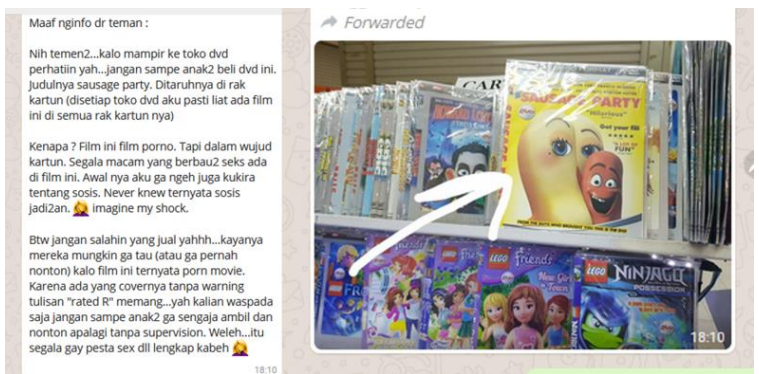

Gambar 4. Contoh penyebaran informasi melalui Whatsapp Sumber: Peserta Pelatihan, 2018

Pada gambar 4 secara agresif masyarakat menyebarkan informasi dari satu grup ke grup yang lain tanpa mencoba mengetahui secara detail deskripsi dari film. Sausage Party merupakan tiruan film Disney dan Pixar. Ini adalah film komedi fantasi petualangan animasi dewasa animasi. Film yang rilis pada 2016 ini disutradarai oleh Greg Tiernan dan Conrad Vernon dan ditulis oleh Kyle Hunter, Ariel Shaffir, Seth Rogen dan Evan Goldberg (Arya, 2016). Sebagai animasi untuk orang dewasa, film ini tidak disertai dengan deskripsi informasi yang jelas pagi penontonnya sehingga memungkinkan anakanak turut serta menikmati tayangan ini. Sedangkan sebagian orang lebih dulu menerima informasi yang tersebar di media sosial tanpa mencoba secara bijak memahami konten sesungguhnya.

Atas dasar temuan ini maka dalam program pendampingan, tim menyisipkan materi mengenai "Perilaku Bijak dalam Berinternet". Dalam materi yang disampaikan yakni bagaimana cara menyikapi informasi yang mereka terima artinya literasi media menjadi penting dalam hal ini.

d. Kepemilikan media digital di rumah tidak bisa diakses langsung oleh ibu-ibu karena digunakan oleh anak-anak mereka

Dinamika yang terjadi pada kelompok sasaran tidak secara merata dirasakan oleh perempuan karena realitasnya sebagian dari mereka justru tidak memiliki kesempatan 
JPPM (Jurnal Pendidikan dan Pemberdayaan Masyarakat), 8 (1), 2021 - 27

Dhyah Ayu Retno Widyastuti, Irene Santika Vidiadari

untuk mengakses handphone di lingkungan keluarganya. Beberapa alasan seperti kepemilikan di rumah hanya satu buah namun cenderung digunakan oleh anak-anak atau suami mereka.

e. Pemanfaatan media untuk akses informasi mengenai kesehatan reproduksi perempuan rendah

Hasil pendampingan melalui proses diskusi yang dilakukan menunjukkan bahwa akses informasi melalui handphone yang terhubung dengan internet untuk kesehatan reproduksi sangat terbatas atau cenderung belum dilakukan oleh perempuan kelompok sasaran. Meskipun mereka menganggap penting informasi ini namun realitasnya mereka memiliki keterbatasan dalam memanfaatkan media yang relevan dengan kebutuhan informasi perempuan. Oleh karena itu, tim memberikan pelatihan mengenai pentingnya kesehatan reproduksi perempuan dan cara memanfaatkan media untuk memenuhi kebutuhan ini.

Beberapa catatan penting selama proses pengabdian kepada masyarakat yakni bahwa pada tahap persiapan, tim menggali kebutuhan kelompok sasaran dan ditemukan adanya kebutuhan untuk meningkatkan kapasitas ibu-ibu PKK dalam hal literasi media dan pengetahuan mengenai kesehatan reproduksi. Kebutuhan ini berangkat dari hasil pengamatan yang menunjukkan bahwa ibu-ibu PKK di Dukuh Plumbon memiliki anak yang saat ini berada pada usia remaja awal (12-15 tahun). Pada proses pendampingan anak (khususnya mengenai pengawasan anak pada saat menggunakan media), ibu-ibu PKK mengalami kesulitan. Hal ini disebabkan karena para ibu merupakan pengguna media tahap awal, artinya mereka masih mengalami transisi dari penggunaan telepon genggam yang hanya bisa untuk menelepon dan SMS ke gawai pintar yang bisa digunakan untuk mengakses internet. Tim melakukan penggalian kebutuhan ini bersama perangkat RT setempat melalui diskusi. Selanjutnya, tim menyusun materi yang dibutuhkan dan menyepakati waktu pelaksanaan.

Pada tahap pelaksanaan program, tim merancang 6 kali pertemuan sejak bulan April hingga Agustus 2018 dengan materi pengenalan media komunikasi, pemanfaatan media, literasi media, pengenalan konsep gender, pengenalan kesehatan reproduksi anak dan peran orang tua dalam pendidikan seks remaja. Materi ini disusun dengan mempertimbangkan kebutuhan kelompok sasaran. Pada pelaksanaannya, tim melakukan pendampingan dengan memanfaatkan kegiatan arisan PKK RT. Secara keseluruhan, program pengabdian yang dilaksanakan di kelompok ibu-ibu PKK RT berjalan dengan lancar.

\section{SIMPULAN}

Literasi media merupakan kecakapan yang penting dimiliki oleh setiap individu, terutama bagi seorang ibu, yang salah satu perannya adalah mendampingi anak-anaknya. Era teknologi komunikasi dan informasi sekarang ini memungkinkan siapa saja untuk mengakses informasi apapun. Hal ini menjadi tantagan seorang ibu saat menghadpi anak yang sangat adaptif dengan media digital. Program pengabdian yang dilaksanakan di kelompok ibu-ibu PKK RT Sanggrahan, Dukuh Plumbon, Kabupaten Bantul menunjukkan bahwa kelompok sasaran menggunakan media pada tingkat awal, yakni menerima dan mengirimkan pesan, dari yang sekedar telepon lalu ke Whatsapp.

Kegiatan pengabdian yang dilaksanakan memberikan pengetahuan kepada kelompok sasaran agar lebih familiar dengan ragam media sosial yang sekarang ini diakses oleh anak-anak mereka. Hal ini tentu akan mendukung proses pendampingan anak saat mengakses media digital. Kemampuan menyaring berita hoaks yang tersebar melalui media sosial yang mereka miliki, hal ini ditunjukkan dari tanggapan peserta kegiatan pengabdian yang berani mengemukakan pendapat ketika ada anggota yang menyebarkan informasi yang belum tentu kebenarannya di grup Whatsapp. Selain itu, pengetahuan mengenai informasi kesehatan 
reproduksi membantu peserta untuk proses pendampingan anak-anak mereka yang sudah mulai beranjak remaja.

Pada sisi lain, terdapat pula keterbatasan dari kegiatan ini yang meliputi keterbatasan waktu yang dimiliki oleh kelompok sasaran, koordinasi yang tidak satu pintu karena adanya tokoh senior yang lebih disegani warga ketimbang pengurus RT setempat, dan perbedaan later belakang pekerjaan yang membuat adanya kesenjangan pengetahuan tentang media digital.

\section{DAFTAR PUSTAKA}

Aprilia, E. N. (2016). Kemandirian Keluarga Sebagai Upaya Pencegahan Perilaku Seks dan Kehamilan Remaja. Profesi, 13(2), 7-14.

Arya. (2016). Sausage Party Review. Retrieved June 30, 2020, from https://mydirtsheet.com/2016/10/24/sausage-party-review/

Astuti, B., S. Sugiyatno, S. Aminah. (2017). The Development of Early Childhood Sex Education Materials for Early Childhood Education (ECE) Teachers. Jurnal Pendidikan dan Pemberdayaan Masyarakat. Voume 4 Nomor 2, 2017, hlm 113-120.

Birowo, M.A., Dhyah A.R. Widyastuti, Thomas A. P. Sidhi. (2019). Konsep Diri Perempuan di Kawasan Rawan Bencana Gunung Merapi. Jurnal ASPIKOM, Volume 4 Nomor 1, Juli 2019, hlm 156-170

European Commission Directorate General Information Society and Media. (2009). Study on Assesment Criteria for Media Literacy Levels. Brussels: European Association for Viewers' Interests.

Friedman, M. (1998). Family Nursing: Theory and Assesment (4th ed). Connecticut: AppletonCentury-Cropts.

Friesem, E. (2016). Drawing on Media Studies, Gender Studies, and Media Literacy Education to Develop an Interdisciplinary Approach to Media and Gender Classes. Journal of Communication Inquiry, 40(4), 370-390.

JISC. (2014). Developing Digital Literacies. Retrieved July 4, 2020, from https://www.jisc.ac.uk/guides/developing-digital-literacies

Juditha, C. (2019). Literasi Informasi Melawan Hoaks Bidang Kesehatan di Komunitas Online. Jurnal Ilmu Komunikasi Volume 16, Nomor 1, Juni 2019: 77-90.

Kapal perempuan. (2018). Enam Masalah Perempuan Indonesia. Retrieved January 28, 2018, from http://kapalperempuan.org/enam-masalah-perempuan-indonesia/.

Limilia, P., N. Aristi. (2019). Literasi Media dan Digital di Indonesia: Sebuah Tinjauan Sistematis. Jurnal Komunikatif Vol. 8 No. 2 Desember 2019, hlm. 205-222.

Nielsen. (2014). Nielsen: Konsumsi Media Lebih Tinggi di Luar Jawa. Retrieved January 28, 2018, from http://www.nielsen.com/id/en/press-room/2014/nielsen-konsumsi-media-lebihtinggi-di-luar-jawa.html.

Nugroho, R. (2017). Keberdayaan Perempuan Pasca Pelatihan Mengolah Sampah bagi Kelompok Pemberdayaan dan Kesejahteraan Keluarga. Jurnal Pendididkan dan Pemberdayaan Masyarakat, 4(2), 146-156.

Prasanti, D., S. S. I. (2017). Pelatihan Literasi Media Digital bagi Murid-Murid Armidale English College (AEC) di Soreang Kabupaten Bandung Selatan. Jurnal Pendididkan dan Pemberdayaan Masyarakat, 4(2), 157-165.

Pudjiastuti, T.N. (2016). Indonesia dalam Belitan Kejahatan Lintas Negara: Kasus Perdagangan Orang pada Pekerja Migran. Jurnal Penelitian Politik 8(2), 197-211.

Saroh, M. (2016). Perempuan dan Anak Rentan Terlibat Human Trafficking. Retrieved July 4, 2020, from https://tirto.id/perempuan-dan-anak-rentan-terlibat-human-traffickingbGMb.

Saugi, W., Sumarno. (2015). Pemberdayaan Perempuan Melalui Pelatihan Pengolahan Bahan Pangan Lokal. Jurnal Pendidikan dan Pemberdayaan Masyarakat, 2(2), 226-238.

Saripah, I., Shantini, Y. (2016). Implementasi Pemberdayaan Mandiri Program Pendidikan 
JPPM (Jurnal Pendidikan dan Pemberdayaan Masyarakat), 8 (1), 2021 - 29

Dhyah Ayu Retno Widyastuti, Irene Santika Vidiadari

Kecakapan Hidup Perempuan, Jurnal Pendidikan dan Pemberdayaan Masyarakat, 3(2), 176186.

Setyaningsih, R., Abdullah, Prihantoro, E., H. (2019). odel Penguatan Literasi Digital Melalui Pemanfaatan E-Learning. Jurnal ASPIKOM, 3(6), 1200-1214.

Undang-Undang no. 10 tahun 1992 tentang Perkembangan Kependudukan dan Pembangunan Keluarga Sejahtera. (n.d.). No Title.

Wardhani, W. K. (2017). Perempuan, Kelompok Rentan Hadapi Diskriminasi dalam Akses Layanan Kesehatan Seksual dan Reproduksi. Retrieved January 28, 2018, from http://magdalene.co/news-1413-perempuan-kelompok-rentan-hadapi-diskriminasidalam-akses-layanan-kesehatan-seksual-dan-reproduksi. html.

Widodo, F. (2018). Masyarakat Pada Pembangunan Infrastruktur Dalam Konteks Pemberdayaan Masyarakat. Jurnal Pendidikan Dan Pemberdayaan Masyarakat, 5(2), 108-121.

Widyastuti, D.A.R., F.A. Herawati, T.D.Wulandari, P. Arifin, Y.D. Handarkho. (2016). 'Bakulan Rt 36', web media for supporting women's economic empowerment in Yogyakarta. International Journal Economic Policy in Emerging Economies, Vol. 9, No. 2, 2016, p 145157.

Widyastuti, D.A.R., Ranggabumi, N., Thomas, A. P. S. (2016). Literasi Digital pada Perempuan Pelaku Usaha Produktif di Daerah Istimewa Yogyakarta. Jurnal ASPIKOM, 3(1), 1-15. 